\title{
Analysis of Heavy Metal Pollutant in Wangi River Pasuruan and Its Impact on Gambusia affinis
}

\author{
Moh. Awaludin Adam ${ }^{1.2}$, Maftuch ${ }^{3}$, Yuni Kilawati ${ }^{3}$, Siti Nur Tahirah ${ }^{4}$, Yenny Risjani ${ }^{3}$ \\ ${ }^{1}$ Doctoral Student at Fisheries and Marine Sciences of Faculty, Brawijaya University, Veteran-65145, Malang, Indonesia \\ ${ }^{2}$ Academy of Fishery Ibrahimy, Sukorejo-68374, Situbondo, Indonesia \\ ${ }^{3}$ Fisheries and Marine Sciences of Faculty, Brawijaya University, Veteran-65145, Malang, Indonesia \\ ${ }^{4}$ School of Marine and Environmental Sciences, Universiti Malaysia Terengganu, 21030, Malaysia
}

\begin{abstract}
Pollution that occurred in Pasuruan area's watershed Wangi-Beujeng river, District of Beji, Indonesia has been initiated in 2007 and continues to this day. The activity was caused by many factors such as the industrial (I), household wastes (II) and agriculture wastes (III) as well as the erosion process. The aims of this study to analyzed the heavy metal pollution that occurs in the Wangi river flow and the effect of gill histology and antioxidant activity on gambusia fish. The research method of observation at river flow and sampling for laboratory test.Three sites were assigned for chemical sampling and tissue histologycal in this study. Fish (Gambusia affinis, local name: Gatul) and water were used as indikatorfrom each site to determine of cadmium $(\mathrm{Cd})$, lead $(\mathrm{Pb})$ and mercury $(\mathrm{Hg})$ concentration using Atomic Absorption Spectrophotometry (AAS). The study was indicated that the streams previously used by residents for daily activities. Results showed level of cadmium $(\mathrm{Cd})$, lead $(\mathrm{Pb})$ and mercury $(\mathrm{Hg})$ in Gambusia affinis exceeded the permissible standard (0.01 ppm Cd;0.03 ppm Pb;0.001 ppm Hg)respectively. Based on histologycal, the tissue showed of damage ofchloride cell (CC) which was used in ion homeostasis process and heavy metal route in grill fish. While protease activities, CAT, MDA and peroxidasse was increased in each sampling area, with significant different $(>0.95)$ between the three sampling sites
\end{abstract}

Keywords: Chloride cell, Heavy metal, Toxicity, Wangi river

\section{INTRODUCTION}

Pollution of industry wastes will be accumulation of water pollutant [1], [2]. Its substance from industry wastes have within it heavy metal[3]. As research was result contains of heavy metal pollutant a toxic [4]are mercury $(\mathrm{Hg})[5]$, cadmium (Cd)[6], chromium (Cr)[7], lead $(\mathrm{Pb})[8]$, etc. If a toxic expelled to environment can dangerous of organism[7]. Toxic of capacity heavy metal reason enzyme block ways[9], with the result that disturbed of metabolism[10]. Although if heavy metal absorbs at human body can be allergy or carcinogen [11]and deaths if maximum of concentration[12].

One of the case water pollution is Wangi river bleach water condition and surface measurement of putrid taste. Heavy metals increase in intensity with the entry of waste and some other pollutants into the waters [8] and end or settle in the mouth of the river before heading into the sea [5]. Waste contains heavy metals, usually from industry, household and agricultural activities [13], as is the case in the Wangi river.

\footnotetext{
Correspondence address:

Moh. Awaludin Adam

Email : ar.adam87@yahoo.com

Address : Academy of Fishery Ibrahimy, Sukorejo-68374
}

But, specially study about heavy metal analysis and identification at Wangi river-Beujeng, Beji district pollution case not identified. Whereas, but actually the case of $\mathrm{Cd}$ are dangerous to human body [14]and water environment[15]. The first case $\mathrm{Cd}$ pollutant at Japan tragedy to come to the surface itai-itai disease as toxic to fisherman[16] and families and deaths arrived 100 human inhabitant[17].

Species of organism various can be accumulated heavy metal in the big quantity as fish, mollusca, plants and microorganism[18].This study willfocuson heavy metal accumulation in fish, and Gatul (Gambusia affinis) used as biomonitoring tool from Wangi River. Fish from Poecilidae family[19]are one of the freshwater fish lives in water and wide dispersed on tropical[20]. Its easy adaptation and high tolerant to temperature and salinity[21], moreover water pollutant[22].

Cadmium (Cd), dangerous heavy metal, spread out as environmental contaminant. The main route of $\mathrm{Cd}$ were respiratory track and digestion system [23]. Exposure toward environment and biota inside were come from various contamination source especially waste that spill out into environment. This exposure can caused dysfunction of kidney, liver toxicity, genotoxicity 
and apoptosis effect depend on doses, route and duration of exposure[24].

One of Cd toxicity aspect is cytotoxic of ROSgeneration which caused damage in macromolecule biology oxidative[25]. In cell, keep the balance between ROS production and antioxidant was important in transport mechanism of ROS[24]. Superoxide dismutase (SOD), Catalase (CAT) and Glutathione peroxide (GPx) are part of antioxidant system that protects cells against ROS. $\mathrm{O}_{2} \mathrm{~N}$ was shredded by SOD and $\mathrm{H}_{2} \mathrm{O}_{2}$ then decomposed by GPX and CAT. When ROS generation rate exceeds the cell's antioxidant capacity, severe oxidative stress will result in oxidative damage. In addition to the enzyme index, the central measure of oxidative stress is lipid peroxidation (LPO), as indicated by the level of malondialdehyde (MDA), which can be accumulated as consequence of cell damage[26].

$\mathrm{Cd}$ contributes to increase the oxidation reaction of exposed cells. The production of ROS induced by $\mathrm{Cd}$ is a response to its toxic effect in many tissue and organs. One of the major mechanisms behind $\mathrm{Cd}$ toxicity is associated with oxidative stress. Cd itself is not able to produce free radicals directly, since it has only one oxidative process, however, indirect generation of radicals involving superoxide radicals, hydrogen radicals and nitric oxide has been reported[25]. Some experiment also confirm the generation of hydrogen peroxide which turn may be significant source of radicals through the chemical reaction of Fenton and Haber-Weiss. ROS has been implicated in chronic $\mathrm{Cd}$ nephrotoxicity, immunotoxicity and carcinogenesis. Because $\mathrm{Cd}$ interferes with the $\mathrm{SH}$ group, it effects the function of many proteins but also the redox status of the cell and hence the cellular level of the active species redox. Sensitivity of the cell relative-withdifferentprotein critical targets, however, it is not well marked[27].

The aims of this study to analyzed the heavy metal pollution that occurs in the Wangi river flow and the effect of gambusia fish on gill histology and some of its antioxidant enzyme activity. Discover environmental condition in the flow of Wangi River, especially in 3 different sites there are industrial area, household area and agriculture area. Those areas are suspected has a great contribution in degradation of environment quality in the Wangi River's flow. The effects of environmental degradation will discovered through Gambusiafish by observed the gill histology, heavy metal accumulation and the influence on antioxidant activity.

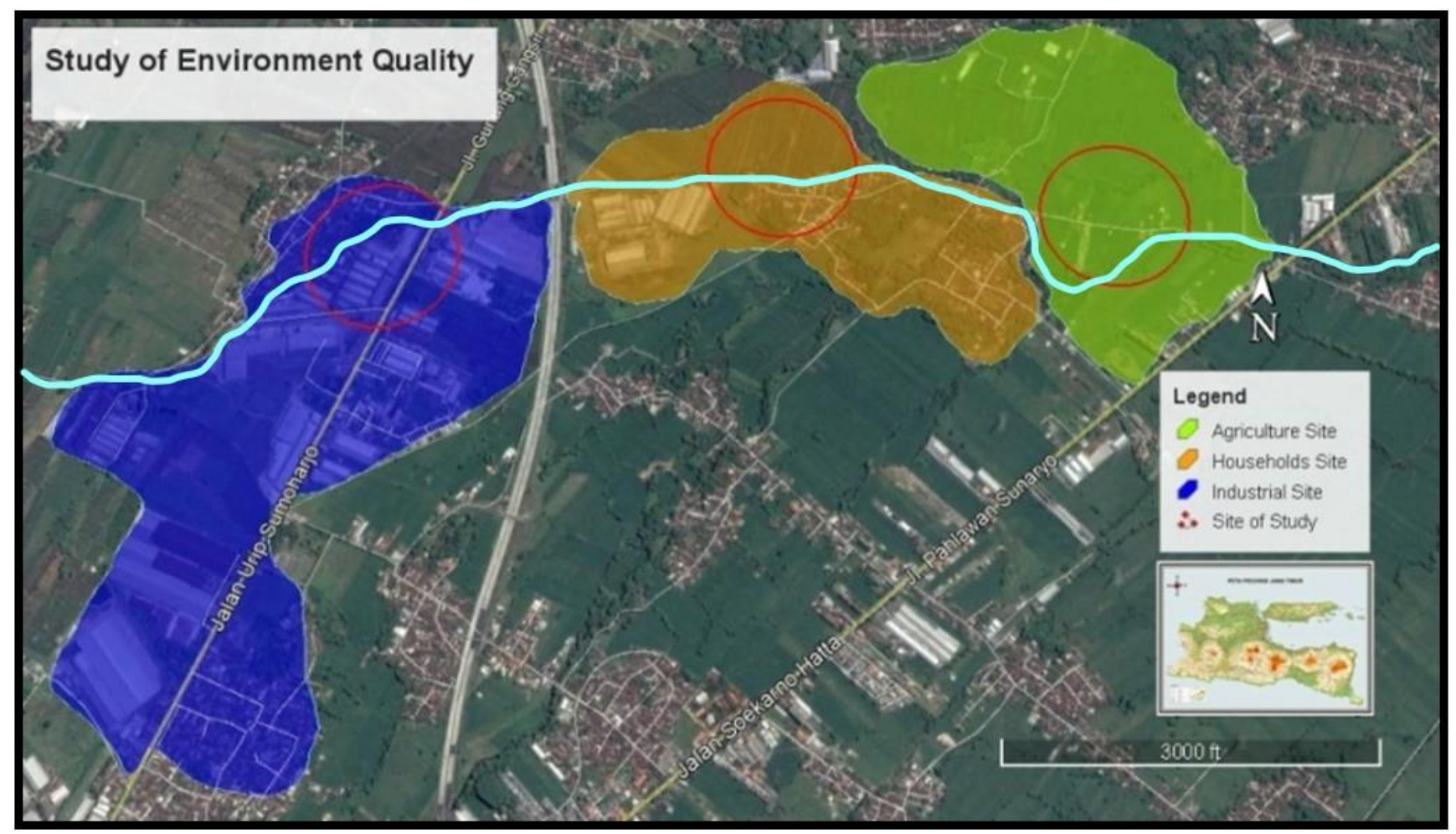

Fig. 1. The Wangi River (blue line) located in East Java, Indonesia. The three sampling areaswas marked by the different pointer; (I) Sampling site at industrial wastes; (II) Sampling site at household wastes; (III) Sampling site in agriculture wastes. 


\section{MATERIAL AND METHODS}

\section{Study Area}

The Wangi River in East Java has flow from the spring at ArjunoMount to The Prigen waterfall. The river flows through the following district, which define the prominent zones; Pandaan, Beujeng, Beji and Bangil. Water, sediment and fish samples were taken from seven different sites, but only three different sites were influenced by wastes that used for further investigation.

The chemical-physical characteristics of aquatic environment was listed in Table1, providing several water quality parameters, including dissolved oxygen (DO), temperature, $\mathrm{pH}$, chemical oxygen demand (COD) and biological oxygen demand (BOD) [13]. The Wangi River of Beujeng were influenced by wastes are characterized by a relatively higher BOD and COD and a lower amount of dissolved oxygen (DO).

\section{Sample Collection}

The water, sediment and fish was collected from Wangi River, Pasuruan in three different site (Fig 3). The flame atomic absorption spectrometryfromAtomic Absorption Spectrophotometry(AAS) [28] type AA6200 (Specification; Double-beam system (using chopper mirror); Aberration-corrected CzernyTurner monochromator; Holographic grating; Shimadzu corporation- 2014-Japan). The fish samples were collected from Wangi River, Pasuruan and cleaned thenwashed with distilled water. Sample collection with method Irianto and Austin on [13] modified, body fish dried were dried at roomtemperature for two weeks. The dried tissues weredigested as following: $1.0 \mathrm{~g}$ of each was dissolved in $1 \mathrm{M}$ nitric acid $(10 \mathrm{ml})$, boiled to complete thedissolution and filtrated. The obtained precipitate waswashed with nitric acid (1 M) and transferred to 25 mlvolumetric flask and fill up to the level with de-ionizedwater.

\section{Preparation of gill}

The gills were immediately removed, packed in plastic bags and transported to the laboratory in ice cooled box where they were stored at $20{ }^{\circ} \mathrm{C}$. Latter the gills were dried at $105^{\circ} \mathrm{C}$ in agravity oven to constant weight[29]. The dried fish gills for five fish from each sampling station weremixed and homogenized by grinding with a pestle and mortar into a fine powder and placed inwell labeled plastic bags.

\section{Histological observation}

Gill tissues were carefullyexcised modified from[30], fixed in $10 \%$ buffered formalin for 24 hours, followed bydehydration with ethanol and toluene series and embedded inparaffin. Approximately $4 \mathrm{~mm}$-thick serial sections were obtainedand stained with hematoxylin and eosin (H\&E) for observationwith a light microscope (Olympus BX51).

\section{Hydrogen peroxide levels}

The tissue hydrogen peroxide level was determined according to the methods that provided by Philip J. [31] using HRP and phenol red. The values were expressedasnanomole of hydrogen peroxide per milligramprotein.

\section{Catalase activity}

Catalase activity (EC 1.11.1.6)was estimated by the method described[32]. Homogenates (4\%) of tissues wereprepared in cold phosphate extraction buffer $(50 \mathrm{mmol}, \mathrm{pH} 7)$ using a glass Teflon homogenizer and then centrifugedat 3,000 rpm for $15 \mathrm{~min}$. To the supernatant $(1 \mathrm{ml})$, $10 \mathrm{mmol}$ of hydrogen peroxide in $2 \mathrm{ml}$ ofphosphate buffer (50 mmol, $\mathrm{pH} \mathrm{7}$ ) was added as asubstrate for catalase to initiate the incubation. Thedecrease in absorbance of the sample was measured at240 $\mathrm{nm}$ using UV-visible spectrophotometer (Hitachi,model no. U-3310). The values were expressed as millimoleof hydrogen peroxide decomposed per milligramprotein per minute.The value was compared with the absorbance standardkit CAT merk stressmarq Canada, to obtain an estimate of the same protein value in the treatment sample,10 $\mathrm{\mu g} / \mathrm{ml}$ of SPC-115 was sufficient for detection of $\mathrm{Cu} / \mathrm{Zn} / \mathrm{Cd} \mathrm{CAT}$ in $20 \mu \mathrm{g}$ of colorimetric immunoblot analysis.

\section{Estimation of protease activity}

Protease activities in the tissues were estimated bytheninhydrin method as described by [33]. Homogenate (4 \%) was prepared incold phosphate extraction buffer $(50 \mathrm{mmol}, \mathrm{pH}$ 7)and centrifuged at 3,000 rpm for $15 \mathrm{~min}$. To 2 mlof the supernatant, $0.5 \mathrm{ml}$ of $1 \%$ casein and 2 mlof $0.1 \mathrm{~mol}$ phosphate buffer $(\mathrm{pH} 5)$ were added. Thecontents were mixed well and incubated at $37{ }^{\circ} \mathrm{C}$ for30 $\mathrm{min}$. The reaction was stopped by adding $2 \mathrm{ml}$ of $2 \%$ ninhydrin reagent. Again, the contents were mixed thoroughlyand placed in a boiling water bath for $20 \mathrm{~min}$. The solution was cooled and made to $10 \mathrm{ml}$ withdiluents (distilled 
water and n-propanol in 1:1 ratio). The optical density of the color developed was measuredusing a spectrophotometer at $570 \mathrm{~nm}$ against areagent blank. The protease activity is expressed asmicromole of tyrosine equivalents per milligram proteinper hour.

\section{Lipid peroxidation estimation}

MDA, the secondary product of lipid peroxidation, was estimated in the tissue homogenates utilizing thecolorimetric reaction of TBA [34]. Itgives an index of the extent of progress of lipid peroxidation, and since the assay estimates the amount ofTBA reactive substance, e.g., MDA, it is also known asTBARS test. Tissue homogenates (16\%) were preparedin cold 50 mmolTris-hydrochloric acid $(\mathrm{HCl})(\mathrm{pH}$ 6.8) extraction buffer. To $0.8 \mathrm{ml}$ of the homogenate, 2 $\mathrm{ml}$ of $15 \%$ trichloroacetic acid (TCA) was added andcentrifuged at 5,000 rpm for $15 \mathrm{~min}$. To the entiresupernatant, $0.7 \mathrm{ml}$ of TBA reagent (1\%) was added,and the test tubes were covered with aluminum foilfollowed by incubation in a shaking water bath for60 $\min$ at $100{ }^{\circ} \mathrm{C}$.

Tabel 1. Water Quality in three different areas of Wangi-Beujeng River

\begin{tabular}{llll}
\hline \multicolumn{1}{c}{ Parameter } & Area I (Industrial Area) & Area II (Household Area) & \multicolumn{1}{c}{$\begin{array}{c}\text { Area III (Agriculture } \\
\text { Area) }\end{array}$} \\
\hline $\mathrm{DO}(\mathrm{mg} / \mathrm{L})$ & 7.86 & 7.92 & 7.94 \\
$\mathrm{pH}$ & 6.5 & 6.7 & 7.1 \\
Temperature $\left({ }^{\circ} \mathrm{C}\right)$ & $28-30$ & $28-31$ & $29-30$ \\
$\mathrm{COD}(\mathrm{mg} / \mathrm{L})$ & 45 & 30 & 53 \\
$\mathrm{BOD}(\mathrm{mg} / \mathrm{L})$ & 30 & 18 & 42 \\
Detergent & $22.2 ; 374$ & $35.39 ; 460$ & $27.17 ; 365$ \\
\hline
\end{tabular}

Tabel 2. Heavy metal in three different areas of Wangi-Beujeng River

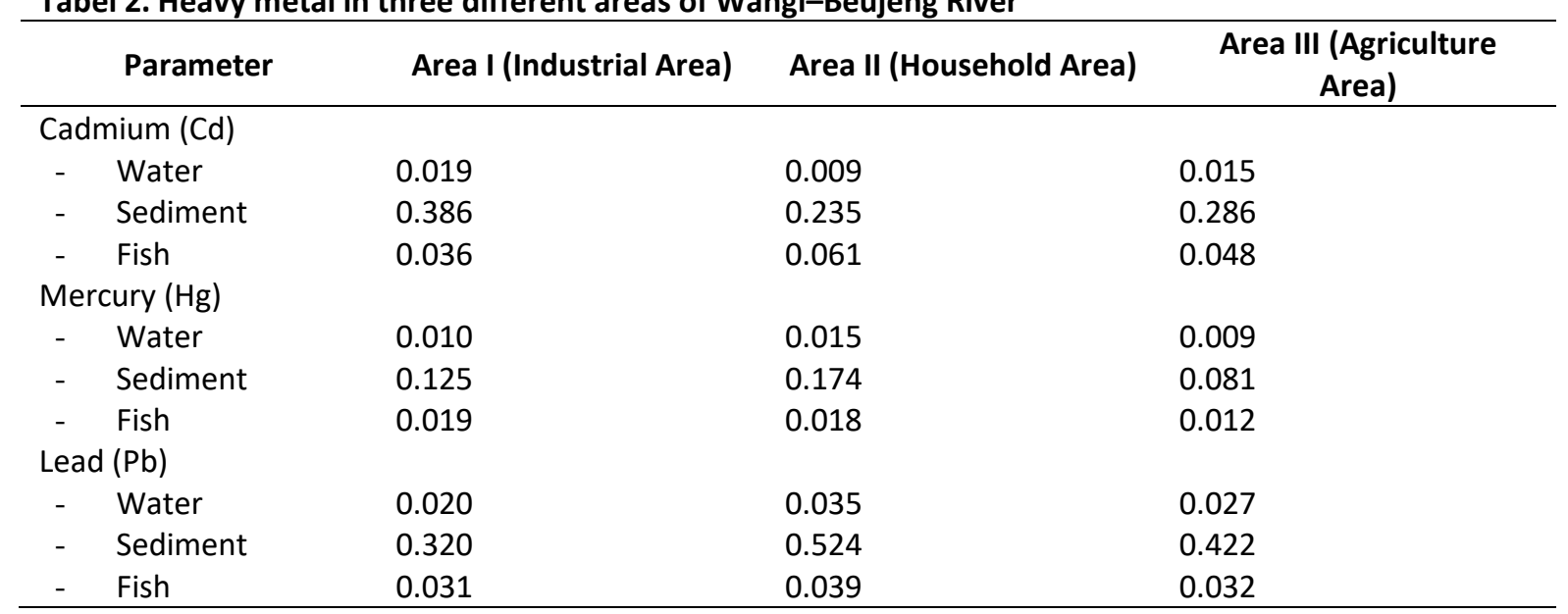
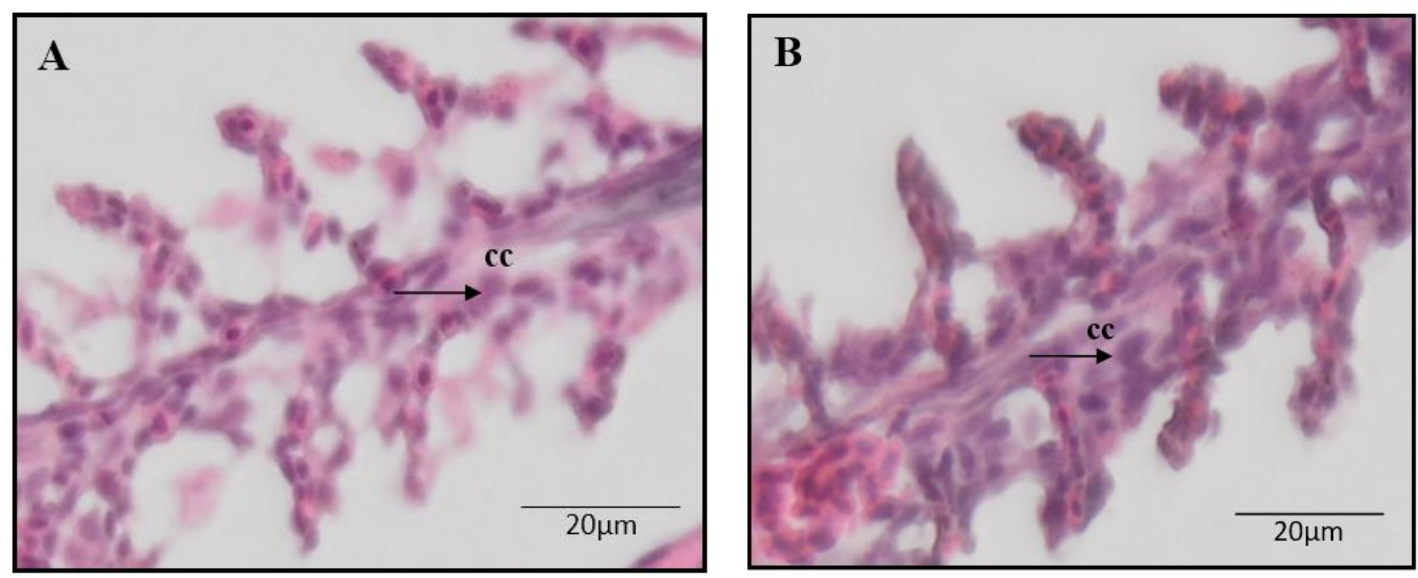


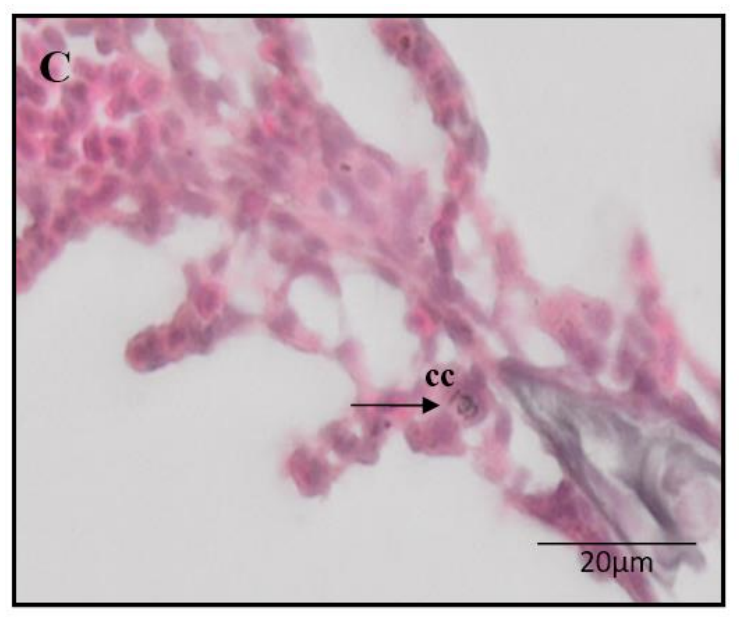

Fig. 2. Gills structure of fish. A) Industrial area, B) Household area, C) Agriculture area.Chloride cell (cc) from three different areas was changed. Severe damage of chloride cell showed in gill from industrial area.

The tubes were then transferred toice-cold water for $10 \mathrm{~min}$, and the absorbencies wereread at 532 $\mathrm{nm}$ against a reagent blank. The rate of lipidperoxidation (LPO) was expressed as nanomoleofTBARS formed per milligram of protein using a molarextinction coefficient of $1.56 \times 10-5$ $\mathrm{mol}-1 \mathrm{~cm}-1$.

\section{Statistical analysis}

Data correspond to the average of three replicates with ANOVA analysis SPSS [35]. Thedata obtained were analyzed statistically by following Duncan's and Tukey'smultiple range test.

\section{RESULT AND DISCUSSIONS}

\section{Quality of Water Environment}

Water pollution observation data based on change level $\mathrm{BOD}_{5}, \mathrm{COD}, \mathrm{DO}$, temperature, $\mathrm{pH}$, Detergent and metal observation $(\mathrm{Pb}, \mathrm{Cd}$ and $\mathrm{Hg}$ ) is presented in Table1 and Table 2.The result of water quality from three different sampling areas was showed in Table 1.Level of $\mathrm{DO}, \mathrm{pH}$ and temperature were in normal condition for the life of aquatic organism. However, the COD and $\mathrm{BOD}_{5}$ levels were in quite alarm as it shows well above the limits for the life aquatic organism. Tolerance of COD between $20-30 \mathrm{mg} / \mathrm{L}$ while the limits for $\mathrm{BOD}_{5}$ is $8-15 \mathrm{mg} / \mathrm{L}$. Meanwhile, field observation showed COD; $45 \mathrm{mg} / \mathrm{L}$ (I), 30mg/L (II) and $53 \mathrm{mg} / \mathrm{L}$ (III) while BOD5; $30 \mathrm{mg} / \mathrm{L}$ (I), 18mg/L (II) and $42 \mathrm{mg} / \mathrm{L}$ (III).

Small proportion of detergent can be classified as having a medium toxicity (10-100 $\mathrm{mg} / \mathrm{L})$ and a few have very low toxicity (up to $10,000 \mathrm{mg} / \mathrm{L}$ ). Detergent can cause damage to the gill respiration epithelium such as enlargement and vacuolation of the cell with dystrophic to necrobiotic changes. The clinical signs of poisoning include respiratory disorder and later by inactivity. The characteristic in the patho-anatomic examination are increase amount of mucus on the skin and in the gill, and congestion to oedematous swelling of the gill apparatus[36].

The concentration of heavy metals ( $\mathrm{Cd}, \mathrm{Hg}$ and $\mathrm{Pb}$ ) determined in water, sediment and fish at three sampling area given in Table 1 . The range of Cd was $0.36-0.061 \mathrm{mg} / \mathrm{L}$ with NO significant different $(>0.95$ ) between the three sampling sites, while the range of $\mathrm{Hg}$ was $0.012-0.019 \mathrm{mg} / \mathrm{L}$ and $0.031-0.039 \mathrm{mg} / \mathrm{L}$ for $\mathrm{Pb}$. The highest concentration of the heavy metal in fish was recorded for $\mathrm{Cd}$, followed by $\mathrm{Pb}$ and $\mathrm{Hg}$, where $\mathrm{Cd}$ recorded higher concentration was collected from household area (Fig.1). The same trend was found in the level of $\mathrm{Pb}$.

Water sample from three different sites showed (Table 2) concentration of $\mathrm{Pb}$ was highest compared to $\mathrm{Hg}$ and $\mathrm{Cd}$. The result indicated that $\mathrm{Pb}$ in water and sediment samples (Table 2) were higher than $\mathrm{Cd}$ and $\mathrm{Hg}$. But in fish samples observations showed that $\mathrm{Cd}$ was higher than $\mathrm{Pb}$ and $\mathrm{Hg}$. The was indicated that the industrial area contributes the highest heavy metal waste and the type of metal $\mathrm{Cd}$ with the highest concentration in the waters and fish samples.Fishcan accumulate cadmium from the water and eating foods contaminated withcadmium (contaminated food chain). It is important to note that bioaccumulationmagnificationoccur when a substance cannot be easily metabolized or 
excreted[16]. Diverse industrial wastes have aggravaeted the problem of water pollution as and this problem becomes complex with of nondegradability of inorganic pollutan like heavy metals[37].

However in small amount, exposure of heavy metal in long period can cause accumulation in aquatic organism body. General effectscaused by accumulation of heavy metal are damage of central nervous system and parenchymatous organs. Very small concentration of $\mathrm{Cd}$ may produce specific effect after long exposure period. $\mathrm{Hg}$ compound can cause damage to some vital tissue and organ in fish and may also have a harmful effect on reproduction[16].

\section{Histology of gill fish}

Appearance on histology of gills of Gambusia fish taken from samples of industrial, household and agriculture areas showed gill damage (Fig. 2). The damage was clearly seen in the chloride cell. From three different areas, Industrial area showed severe damage in the chloride cell compare to Household and Agriculture area. Chloride cells play an important role in the homeostasis process of fluid entry into the gills fish. This process allows heavy metal to be first absorbed into the body through a chloride cells. Observation result has indicated that damage occur when organism was exposed by waste containing with heavy metals[38]. The statement of [4]asked of gill destined for histopahologic can be either excised from the carcass as whole gill arches or individual filaments, or examined in whole-body sections, in the case of small fishes. The hotomicrographs indicated to follow this approach can lead to inappropriate diagnoses of lamellar epithelial hyperplasia (LEH), lamellar fusion, lamellar loss or atrophy or chloride cell hyperplasia.

\section{Heavy metal induced Oxidative Stress}

The result data showed that catalase and protease enzyme activity in industrial area $(0.562 \pm 0.192 ; 0.932 \pm 0.049)$ greater than other areas $\quad(0.462 \pm 0.114 ; 0.877 \pm 0.112,0.265 \pm 0.064$; $0.937 \pm 0.133$ ) (Fig 3). Data's showed a high effect of industrial waste on the activity of CAT and protease enzymes. Catalase and protease can be endogeneous antioksidants which function to neutralize free radicals[39]. While the activity of $\mathrm{H}_{2} \mathrm{O}_{2}$ and MDA tends to decrease in industry area $(2.167 \pm 0.242 ; 21.278 \pm 2.749)$ and increase in other area $\quad(6.141 \pm 0.604 ; 28.222 \pm 5.49, \quad 18.235 \pm 0.66$; $25.222 \pm 12.4$ ) (Fig 3). Data's showed a low effect of industrial waste on the activity of $\mathrm{H}_{2} \mathrm{O}_{2}$ and MDA, lack of the role of $\mathrm{H}_{2} \mathrm{O}_{2}$ and MDA in reducing free radicals, with significant different $(>0.95)$ between the three sampling sites. The happened because of the increase in antioxidants with the entry of heavy metals into the fish body. Such a statement[37] asked the heavy metal intake in body of living organism can occur through the air, water and food consumed or it can be said that accumulates heavy metals in the body of a living thing through the food chain. Organism needs heavy metal as essential metals in metabolic process and also as co-enzyme factors but in very small amount. When organisms absorbthe metal more than the safe limits, the body will be harmful, because it will be poison that can disrupt the metabolic[6].

But $\mathrm{H} 2 \mathrm{O} 2$, MDA and protease activity in household and agriculture highest industrial, could be the influence of household and agriculture waste containing detergent and pesticides higher so that the effect on existing antioxidants. In the statement [15] as the respiratory system, the absorption of molecular oxygen and transformation into the reactive oxygen of the compound, which a represented of defense mechanisms of inflammation. The physiologically important role of oxygen reactive compounds with a certain concentration capable of modulated reactive oxygen sensitive signals and improving function immunologic cellular [22]. The occurrence of increased and decreased enzyme work is greatly influenced by environmental conditions. The heavy metal in our bodies will also trigger ROS as a result of the deactivate of antioxidant enzymes such as Superoxide dismutase (SOD), Catalase (CAT), and GlutationPeroxidase (GPOD), which function as antioxidants [41]. The formation of ROS in our body is also caused by oxidative stress, ROS will easily damage peroxide fat from the pleated membrane, cell membrane from phospolipid, and lipoprotein by spreading in chain reaction [42], [43].

Heavy metals are harmful polluting substances, the metals that enter into our body through our digestive system will react with the element of sulfur and enzymes in our body so that the enzyme will not work properly but also heavy metals that enter into our body will also react with the Cluster carboxylate $(-\mathrm{COOH})$ is also amino ($\mathrm{NH} 2$ ) in amino acids [37]. Free radicals are basically unpaired molecules in their chemical structures so that these free radicals will look for couples to bond.Basically all biomolecules pair up to achieve stability, so to achieve this stability free radicals will look for other free electrons to bind to achieve stability. 

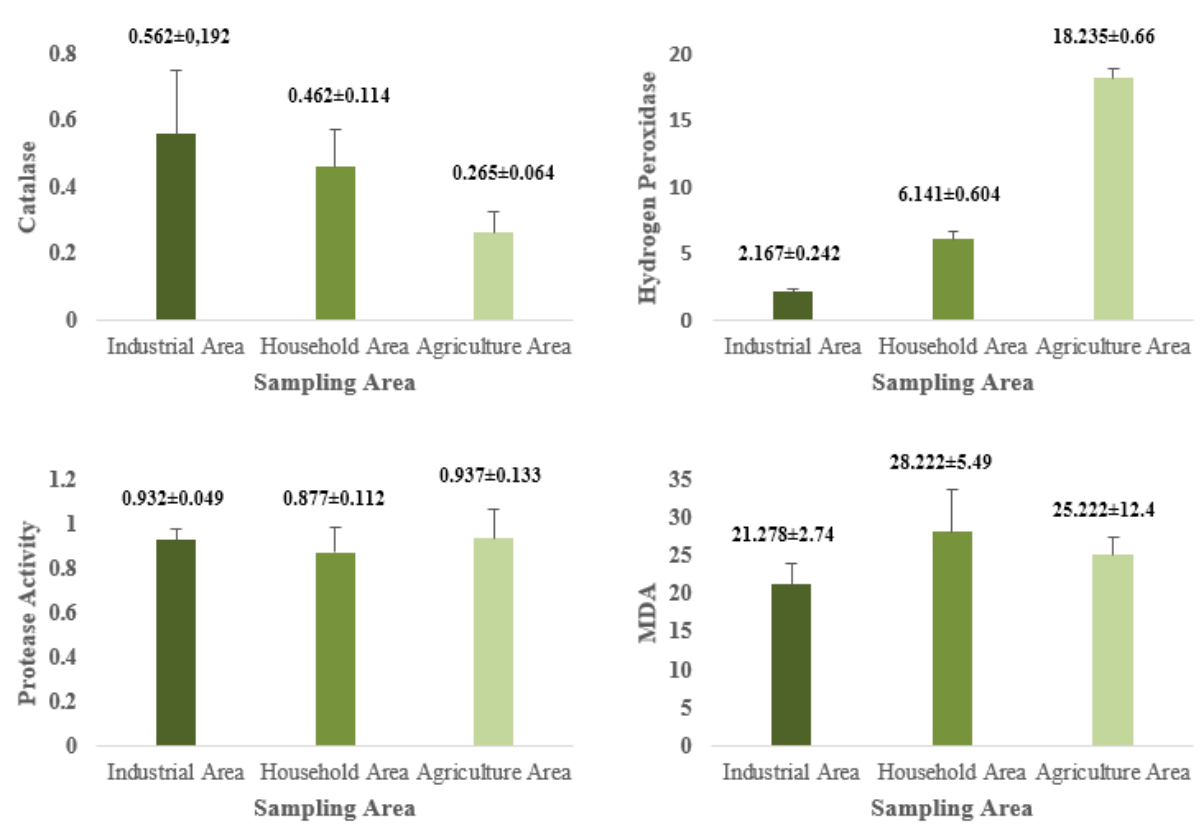

Fig. 3. Indicator of oxidative stress activity. Catalase (CAT, $\mu \mathrm{mol} \cdot \mathrm{min}^{-1} \cdot \mathrm{mg}$ protein $\left.{ }^{-1}\right)$, Hydrogen peroxidase $\left(\mathrm{H}_{2} \mathrm{O}_{2}, \mu \mathrm{mol} . \mathrm{mg}\right.$ protein $\left.\mathrm{n}^{-1}\right)$, Protease activity (PA, mmol.min ${ }^{-1} . \mathrm{mg}$ protein $\left.{ }^{-1}\right)$ and Lipid peroxidation estimation (MDA, $\mathrm{mol}^{-1} \mathrm{~cm}^{-1}$ ) from industrial, household and agriculture area was increased.The data's suggest a significant difference in oxidative stress activity against heavy metal waste discharges.

The nature of oxygen $\left(\mathrm{O}_{2}\right)$ is essentially an electron acceptor so that it will receive free electrons even when it reaches stability, thus forming superoxide (02.-) these free radicals which bind with oxygen are called Reactive Oxygen Species (ROS), $X++Y-X .+Y$ : (The process of occurring oxygen species) [37], [40].

ROS can attack all types of biomolecules such as nucleic acids, proteins and amino acids later on interfere with metabolism. DNA damage is a consequence of the modification of genetic material resulting in cell death, mutagenesis, carcinogenic and aging [31], [39], [44] in our body, ROS is generated by metabolic processes which will be used programmatically to disable cells. ROS consist of Superoxidaradical (O2-), Hydrogen Peroxide (H2O2), Hydroxyl Radical (OH) and Singlet Oxygen (O-2) which increase when exposed to UV rays, ionic radiation and pollution (heavy metal) [9], [15], [22], [45]. Heavy metal toxicities occur when it has exposed and accumulated in living organism through food and water (drinking water) and pollution from wastes.

The observation on indicator of the oxidative stress; CAT, H2O2 and MDA activity in fish samples from industry, residential and agriculture areas has increased (Fig. 3). This indicate that exposure to waste containing heavy metals be able to activate the performance of enzyme that contain of activity antioxidant in self-defense against foreign matter. Heavy metal pollution is one of the greatest national health problems with referring to peoples eating fish foods, it requires special and intense effort at all levels; individual, groups, national, and international.

Heavy metals are inorganic chemicals that are non- biodegradable, cannot be metabolized and will not break down into harmless forms since they leave biological cycles very slowly[4]. Elements such as cadmium, copper, lead and zinc are considered most dangerous in the ecotoxicological aspect[17]. Metal ions can be incorporated into food chains and concentrated in aquatic organisms to a level that affects their physiological state and causes drastic environmental impact on all organisms[30]. Such health risk may over shadow the cardiovascular benefits from the consumption of certain farmed fish, Moreover, aquaculture products are sometimes banned due to rejection of export consignments.

\section{CONCLUSION}

Based on histology, the tissue showed of damage of chloride cell (CC) which was used in ion homeostasis process and heavy metal route in grill 
fish. While protease, CAT, MDA and $\mathrm{H}_{2} \mathrm{O}_{2}$ was increased in each sampling area, with significant different $(>0.95)$ between the three sampling sites.

\section{ACKNOWLEDGMENT}

This research is one part of the doctoral program from the Ministry of Research, Technology and Higher Education of RI No. 158/SP2H/LT/K7/KM/2018. To the PRIMO Team 19th Japan and all parties involved, especially to the promoters who have provided opportunities in everything.

\section{REFERENCES}

[1] A. Soegianto, N. Moehammadi, B. Irawan, and M. Affandi, "Mercury concentrations in edible species harvested from Gresik coast, Indonesia and its health risk assessment Mercury concentrations in edible species harvested from Gresik coast, Indonesia and its health risk assessment," no. May 2017, 2010.

[2] T. V. Pedersen and P. Bjerregaard, "Cadmium influx and efflux across perfused gills of the shore crab, Carcinus maenas," Aquat. Toxicol., vol. 48, no. 2-3, pp. 223-231, 2000.

[3] U. S. Epa, "AQUATIC LIFE AMBIENT WATER QUALITY CRITERIA CADMIUM - 2016," no. March, 2016.

[4] J. C. Wolf et al., "Toxicologic Pathology," 2014.

[5] A. Soegianto, "Trace Metal Concentrations in Shrimp and Fish Collected from Gresik Coastal Waters , Indonesia," vol. 33, pp. 235-238, 2007.

[6] L. De Recherche and L. R. Es, "Cadmium : Bioaccumulation , Histopathology and Detoxifying Mechanisms in Fish," Am. J. Res. Commun., vol. 1, no. 4, pp. 60-79, 2013.

[7] E. Y. Min, T. Y. Ahn, and J. C. Kang, "Bioaccumulation, alterations of metallothionein, and antioxidant enzymes in the mullet Mugil cephalus exposed to hexavalent chromium," Fish. Aquat. Sci., vol. 19, no. 1, pp. 1-7, 2016.

[8] P. Koedrith and Y. R. Seo, "Advances in carcinogenic metal toxicity and potential molecular markers," Int. J. Mol. Sci., vol. 12, no. 12, pp. 9576-9595, 2011.

[9] P. Checconi, R. Sgarbanti, I. Celestino, D. Limongi, A. T. Palamara, and L. Nencioni, "The Environmental Pollutant Cadmium Promotes Influenza Virus Replication in MDCK Cells by Altering Their Redox State," pp. 4148-4162, 2013.
[10] Z. Rizwan, A. Zakaria, M. Sabri, M. Ghazali, A. Jafari, and F. U. Din, "Effect of Annealing Temperature on the Optical Spectra of CdS Thin Films Deposited at Low Solution Concentrations by Chemical Bath Deposition ( CBD ) Technique," vol. 2, pp. 1293-1305, 2011.

[11] C. Valadez-vega, C. Zú, and J. R. Villagó, "Lead , Cadmium and Cobalt ( $\mathrm{Pb}, \mathrm{Cd}$, and $\mathrm{Co}$ ) Leaching of Glass-Clay Containers by $\mathrm{pH}$ Effect of Food," pp. 2336-2350, 2011.

[12] R. Mani, B. Meena, and K. Valivittan, “METALLOTHIONEIN EXPRESSION IN MARINE CATFISH ARIUS ARIUS LIVER ON EXPOSURE TO CADMIUM USING IMMUNOHISTOCHEMISTRY AND WESTERN BLOT," vol. 6, 2014.

[13] Y. Risjani, J. Couteau, and C. Minier, "Cellular immune responses and phagocytic activity of fi shes exposed to pollution of volcano mud," Mar. Environ. Res., vol. 96, pp. 73-80, 2014.

[14] L. Xue, B. Zhou, X. Liu, W. Qiu, Z. Jin, and Y. Yen, "Wild-Type p53 Regulates Human Ribonucleotide Reductase by Protein-Protein Interaction with p53R2 as well as hRRM2 Subunits 1," pp. 980-986, 2003.

[15] Y. Wang and Z. Hoover, "The Effects of Chronic Exposure to Environmentally Relevant Levels of Waterborne Cadmium on ... The Effects of Chronic Exposure to Environmentally Relevant Levels of Waterborne Cadmium on Reproductive Capacity and Behaviour in Fathead Minnows," no. March, 2014.

[16] S. M. Levit, "A Literature Review of Effects of Cadmium on Fish," no. November, 2010.

[17] M. H. Siddiqui, M. H. Al-whaibi, A. M. Sakran, M. O. Basalah, and H. M. Ali, "Effect of Calcium and Potassium on Antioxidant System of Vicia faba L. Under Cadmium Stress," pp. 6604-6619, 2012.

[18] U. S. Epa, “Aquatic Life Ambient Water Quality Criterion for Selenium - Freshwater," 2016.

[19] R. B. Langerhans, M. E. Gifford, and T. J. Dewitt, "Gambusia quadruncus ( Cyprinodontiformes: Poeciliidae ): a new species of mosquitofish from east-central $M$ ' exico," pp. 1514-1539, 2012.

[20] I. M. K. Abumourad, M. M. N. Authman, and W. T. Abbas, "Heavy Metal Pollution and Metallothionein Expression: A Survey on Egyptian Tilapia," vol. 9, no. 1, pp. 612-619, 2013.

[21] J. Subramaniam, K. Murugan, and C. Panneerselvam, "Eco-friendly control of malaria and arbovirus vectors using the 
mosquitofish Gambusia affinis and ultra-low dosages of Mimusops elengi -synthesized silver nanoparticles: towards an integrative approach ?," 2015.

[22] R. Ashauer, A. Hintermeister, I. O. Connor, M. Elumelu, J. Hollender, and B. I. Escher, "Significance of Xenobiotic Metabolism for Bioaccumulation Kinetics of Organic Chemicals in Gammarus pulex," 2012.

[23] S. Nemmiche, "Oxidative signaling response to cadmium exposure," Toxicol. Sci., vol. 156, no. 1, pp. 4-10, 2017

[24] M. Ouedraogo et al., "Review of current and ' omics ' methods for assessing the toxicity ( genotoxicity , teratogenicity and nephrotoxicity ) of herbal medicines and mushrooms," J. Ethnopharmacol., vol. 140, no. 3, pp. 492-512, 2012.

[25] A. Cuypers et al., "Cadmium stress: An oxidative challenge," BioMetals, vol. 23, no. 5, pp. 927-940, 2010.

[26] B. Ruttkay-Nedecky et al., "The role of metallothionein in oxidative stress," Int. J. Mol. Sci., vol. 14, no. 3, pp. 6044-6066, 2013.

[27] P. Kumar and A. Singh, "Cadmium toxicity in fish: An overview," Environ. Health Perspect., vol. 1, no. 1, pp. 41-47, 2010.

[28] D. Sudunagunta, "Atomic Absorption Spectroscopy: A special emphasis on pharmaceutical and other applications," vol. 5, no. 3, pp. 1614-1619, 2012.

[29] J. Y. Ahn, D. Y. Kil, C. Kong, and B. G. Kim, "Comparison of Oven-drying Methods for Determination of Moisture Content in Feed Ingredients," vol. 27, no. 11, pp. 1615-1622, 2014.

[30] J. Wang et al., "The Effects of Cadmium Exposure on the Oxidative State and Cell Death in the Gill of Freshwater Crab Sinopotamon henanense," PLoS One, vol. 8, no. 5, pp. 1-9, 2013.

[31] G. K. Philip J. Brandhuber, Methods for the Detection of Residual Concentrations of Hydrogen Peroxide in Advanced Oxidation Processes. 2009.

[32] H. U. Bergmeyer, From the Preface to the 1st Edition, Second Edi., no. March 1963. Verlag Chemie GmbH, 1974.

[33] R. S. Bockman and L. De Biochimie, "the Proteolytic Activity of y-Globulin Preparations," pp. 554-563, 1967.

[34] A. Placer, L. Cushman, and B. Connor, "Estimation of Product Dialdehyde)," vol. 364, pp. 359-364, 1966.

[35] A. Bryman and D. Cramer, Quantitative Data
Analysis With SPSS 12 and 13. 2005.

[36] J. O. Duruibe and M. O. C. Ogwuegbu, "Heavy Metal Pollution and Human Biotoxic Effects," Int. J. Phys. Sci., vol. 2, no. 5, pp. 112-118, 2007.

[37] A. R. Nair, O. DeGheselle, K. Smeets, E. Van Kerkhove, and A. Cuypers, "Cadmium-induced pathologies: Where is the oxidative balance lost (or not)?," Int. J. Mol. Sci., vol. 14, no. 3, pp. 6116-6143, 2013.

[38] S. F. Pedersen, J. W. Mills, and E. K. Hoffmann, "Role of the F-actin cytoskeleton in the RVD and RVI processes in Ehrlich ascites tumor cells," Exp. Cell Res., vol. 252, no. 1, pp. 6374, 1999.

[39] B. P. Mohanty, M. R. Mahananda, and S. Pradhan, "Cadmium Induced Toxicity and Antioxidant Activities in Labeo Rohita ( Hamilton )," vol. 1, no. 2, pp. 41-47, 2013.

[40] S. Tang et al., Linking oxidative stress and magnitude of compensatory responses with life-stage specific differences in sensitivity of white sturgeon (Acipenser transmontanus ) to copper or cadmium. 2016.

[41] C. E. M. Vural, "TOXICOLOGICAL EFFECTS , OXIDATIVE STRESS AND BIO-ACCUMULATION IN THE TISSUES OF Phaseolus vulgaris L. BEAN SEEDLINGS FOLLOWING CADMIUM EXPOSURE," vol. 31, no. 1, pp. 92-104, 2012.

[42] N. Ercal, "Effects of Lead and Cadmium on Brain Endothelial Cell Survival, Monolayer Permeability, and Crucial Oxidative Stress Markers in an in Vitro Model of the BloodBrain Barrier," pp. 258-275, 2014.

[43] L. Zhang, J. Gan, C. Ke, X. Liu, and J. Zhao, "Short communication Identification and expression profile of a new cytochrome P450 isoform ( CYP414A1) in the hepatopancreas of Venerupis ( Ruditapes ) philippinarum exposed to benzo [ a ] pyrene, cadmium and copper," Environ. Toxicol. Pharmacol., vol. 33, no. 1, pp. 85-91, 2011.

[44] J. M. Carlson, E. R. Hyde, J. F. Petrosino, A. B. W. Manage, and T. P. Primm, "Comparative Biochemistry and Physiology, Part C The host effects of Gambusia af $\mathrm{fi}$ nis with an antibiotic-disrupted microbiome th, "Comp. Biochem. Physiol. Part C, vol. 178, pp. 163168, 2015.

[45] A. Agrawal, "Toxicity and Fate of Heavy Metals with Particular Reference to Developing Foetus," vol. 2, no. 2, pp. 29-38, 2012. 